\title{
Response of Rice Cultivation to Inorganic and Bio-Fertilizers in New Alluvial Zone of West Bengal
}

\author{
M. Malo*, S. Rath and D. Dutta
}

Department of Agronomy, Bidhan Chandra Krishi Viswavidyalaya, Mohanpur-741252, West Bengal, India

*Corresponding author

\section{A B S T R A C T}

\section{Keywords}

Chemical fertilizer, Bio-fertilizer, Root characteristics, Crop growth, Yield attributes, Rice

Article Info

Accepted:

24 February 2018

Available Online:

10 March 2018
A field experiment was conducted during kharif, 2016 in the experimental farm of Bidhan Chandra Krishi Viswavidyalaya to assess the effect of inorganic and bio-fertilizers on root characteristics as well as different growth and yield parameters of rice. The results revealed that the highest root length, root dry weight, plant height $(105.60 \mathrm{~cm})$, leaf area index (3.81), panicle length $(24.50 \mathrm{~cm})$, number of tillers hill ${ }^{-1}(15.19)$, effective tillers hill $^{-1}$ (13.60), spikelets panicle ${ }^{-1}(94.68)$, filled grains panicle ${ }^{-1}(127)$, test weight $(20.10 \mathrm{~g})$ were observed in $100 \%$ RDF $\left(\mathrm{T}_{2}\right)$ which was statistically at par with $75 \%$ recommended dose of NP $+100 \% \mathrm{RDK}+$ Azotobacter chroococcum @ $5 \mathrm{~kg} \mathrm{ha}^{-1}\left(\mathrm{~T}_{4}\right)$ and $75 \%$ recommended dose of $\mathrm{NP}+100 \% \mathrm{RDK}+$ Bacillus polymyxa @ $5 \mathrm{~kg} \mathrm{ha}^{-1}\left(\mathrm{~T}_{5}\right)$. Similarly, $\mathrm{T}_{2}$ treatment recorded the maximum grain and straw yield $\left(5.66 \mathrm{t} \mathrm{ha}^{-1}\right.$ and $6.99 \mathrm{t} \mathrm{ha}^{-1}$ respectively) and all these were at par with $T_{4}$ and $T_{5}$, exhibiting better potential in improving crop growth and yield parameters of rice in new alluvial zone of West Bengal.

\section{Introduction}

Rice (Oryza sativa L.) is a staple food for about 50 per cent of the world's population that resides in Asia, where 90 per cent of the world's rice is grown and consumed. It constitutes $23 \%$ of the global cereal acreage (680 million ha) and $29 \%$ to the global cereal production (2064 million tons). Rice plays a vital role in our food as well as nutritional security for millions of livelihood. Thus the slogan "Rice is life" by IRRI during 2004 seems to be the most appropriate (Chandrasekaran et al., 2007). Rice ranks second to wheat in terms of area harvested but in terms of importance as a food crop, rice provides more calories $\mathrm{ha}^{-1}$ than any cereal crop (De Dutta, 1981). Besides its importance as food, rice provides employment to the largest sector of the rural population in most of the Asia. With the burgeoning increase of population, demand for food is on high. It has been estimated that rice demand in 2025 will be 765 million tons in the world. At the world level, average rough paddy yield is more than $4428 \mathrm{~kg} \mathrm{ha}^{-1}$ whereas in India it is India 3590 $\mathrm{kg} \mathrm{ha}^{-1}$. In Asia, India has the largest area under rice (41.66 million ha) accounting for 29.4 per cent of the global rice area. Rice is one of the largest traded commodities in the world with a total quantity touching 16.4 million tons. The south east countries account 
for about 40 per cent of the rice trade in the world (Mangla, 2004). Rice is the staple food crop of 63 to 65 per cent people of India. The crop at present is grown in 43 million hectares of land with production of 96.7 million tons. Its production has to be raised to 160 million tons by 2030 with a minimum annual growth rate of 2.35 per cent (Mishra et al., 2013). The important yield limiting factors of rice cultivation are the water and mineral stress, diseases, insect pests, and weeds. To improve and/or stabilize yield, these yield limiting factors should be managed sustainably. Research data related to yield limiting factors indicates that much work is needed to improve rice yield under different agro-ecosystems. The increase in rice production could be achieved through adoption of suitable and newer technologies. Therefore, to sustain the self-sufficiency in rice, additional production of 1.5 million tons is needed every year. Among the limited options, hybrid technology and utilization of bio-fertilizers are the proven technology currently available for stepping up rice production significantly. Bio-fertilizer, an alternate low cost resource have gained prime importance in recent decades and play a vital role in maintaining long term soil fertility and sustainability. They are cost effective, ecofriendly and renewable sources of plant nutrients to supplement chemical fertilizers. Nitrogen fixing and phosphate solubilizing inoculants are important bio-fertilizers used in rice. Among the bio-fertilizers in rice field Azotobacter has been recognized as an important diazotroph colonizing root environment of cereal crops. It fixes atmospheric nitrogen, 25 to $30 \mathrm{~kg}$ per ha. Thus, it can save 25 per cent of fertilizers' nitrogen. Phosphorus solubilizing bacteria solubilizes insoluble forms of phosphorus already present in the soil and makes it available for use of plants. The ground realities are that farmers are still adopting undesired practices because of various reasons like use of old verities, imbalance use of fertilizers, minimum uses of bio-fertilizer etc. Therefore, a technological breakthrough in agro-techniques especially in nutrient management by utilizing bio-fertilizers should be adopted in improving production potential of rice in terms of yield performance in new alluvial zone of West Bengal.

\section{Materials and Methods}

A field experiment was conducted during the kharif season of 2016 at ' $C$ ' block farm of Bidhan Chandra Krishi Viswavidyalaya, Kalyani, Nadia, West Bengal. The experimental farm was situated at $22.5^{\circ} \mathrm{N}$ latitude and $89.0^{\circ} \mathrm{E}$ longitude and at an elevation of $9.75 \mathrm{~m}$ above mean sea level. The soil of the experimental field was new alluvial (type - Entisol) and sandy loam in texture with $\mathrm{pH} 6.81$ and had good water holding capacity and moderate fertility. The sand, silt and clay content of the soil were $54.8 \%$, $21.8 \%$ and $23.1 \%$ respectively and the bulk density was $1.31 \mathrm{~g} \mathrm{cc}^{-1}$. On the other hand, the organic carbon, available nitrogen, phosphorus and potassium content were $0.30 \%, 320.52 \mathrm{~kg}$ $\mathrm{ha}^{-1}, 35.6 \mathrm{~kg} \mathrm{ha}{ }^{-1}$ and $106.2 \mathrm{~kg} \mathrm{ha}^{-1}$ respectively. The experiment consisted of seven treatments viz. $\mathrm{T}_{1}$ : control, $\mathrm{T}_{2}$ : chemical fertilizer at $100 \%$ recommended dose of NPK, $\mathrm{T}_{3}: 50 \%$ recommended dose of $\mathrm{NP}+100 \%$ $\mathrm{RDK}+$ Bacillus polymyxa @ $5 \mathrm{~kg} \mathrm{ha}{ }^{-1}, \mathrm{~T}_{4}$ : $75 \%$ recommended dose of NP $+100 \%$ RDK + Azotobacter chroococcum @ 5 kg ha ${ }^{-1}, \mathrm{~T}_{5}$. $75 \%$ recommended dose of NP $+100 \%$ RDK +Bacillus polymyxa@ $5 \mathrm{~kg} \mathrm{ha}^{-1}, \mathrm{~T}_{6}: 50 \%$ recommended dose of $\mathrm{NP}+100 \% \mathrm{RDK}+$ Pseudomonas fluorescence @ $5 \mathrm{~kg} \mathrm{ha}^{-1}$ and $\mathrm{T}_{7}: 50 \%$ recommended dose of NPK + Bacillus polymyxa @ $5 \mathrm{~kg} \mathrm{ha}{ }^{-1}$. The experiment was conducted in randomized block design with 3 replications. The size of each plot was $5 \mathrm{~m}$ x $3 \mathrm{~m}$. Rice cultivar 'IET4786 (Shatabdi)' was sown. The recommended dose of $\mathrm{N}: \mathrm{P}_{2} \mathrm{O}_{5}: \mathrm{K}_{2} \mathrm{O}$ for rice was $60: 30: 30 \mathrm{~kg} \mathrm{ha}^{-1}$ and the chemical 
fertilizer in the form of urea, single super phosphate (SSP) and muriate of potash (MOP) were broadcasted and incorporated into $15 \mathrm{~cm}$ depth of soil. Half dose of nitrogen and full dose of $\mathrm{P}_{2} \mathrm{O}_{5}$ and $\mathrm{K}_{2} \mathrm{O}$ were applied as basal and remaining half nitrogen was top dressed at 30 days after transplanting (DAT). All the biofertilizers were applied @ $5 \mathrm{~kg} \mathrm{ha}^{-1}$ as seed treatment.

For raising of seedlings about $50 \mathrm{~kg}$ seeds of rice were broadcasted in the 4th week of June in nursery bed for transplanting and about 21 days old seedlings were transplanted in $3^{\text {rd }}$ week of July at a spacing of $20 \mathrm{~cm} \times 15 \mathrm{~cm}$. 23 seedlings per hill were transplanted. Weeding was done manually at 30 and 50 DAT to keep the plot weed free. The seedbed was prepared with irrigation and the water soaked seeds were sown in seedbed provided continuous submergence with water. About 2 $\mathrm{cm}$ water depth was maintained through the nursery period. After transplanting in the main field 2-3 cm water depth and at tillering and panicle initiation stage, alternate wet and dry soil condition was maintained as far as possible. The irrigation was stopped at 15 days before harvesting of the crop. Ten plants were selected randomly from the each plot and root length, root dry weight, plant height, leaf area index, panicle length, number of tillers hill ${ }^{-1}$, effective tillers hill $^{-1}$, number of spikelets panicle $^{-1}$, number of chaffy grains panicle ${ }^{-1}$, number of filled grains panicle ${ }^{-1}$, test weight of grains, grain and straw yield, biological yield and harvest index were recorded.

The data obtained were subjected to statistical investigation following the analysis of variance technique by using software packages of MS Excel and OPSTAT. Statistical significance between means of individual treatments was assessed using Fisher's Least Significant Difference (LSD) at $5 \%$ level of probability.

\section{Results and Discussion}

\section{Effect on root characteristics (root length and root dry weight)}

The effects of inorganic fertilizer and different bio-fertilizers on root length and root dry weight of rice are given in Table 1 and 2 . Among different fertilizer sources, $T_{2}$ treatment i.e. application of inorganic fertilizer at $100 \%$ recommended dose recorded significantly highest root length at all growth stages. At 15 DAT, 30 DAT, 60 DAT and 90 DAT, the maximum root length $(5.56 \mathrm{~cm}, 7.63$ $\mathrm{cm}, 13.98 \mathrm{~cm}$ and $16.73 \mathrm{~cm}$ respectively) were observed in $\mathrm{T}_{2}$ which was statistically at par with all the treatments except control. The biofertilizer based treatments did not show much variation in this aspect from the fully inorganic fertilized plots. As expected the control treatment $\left(\mathrm{T}_{1}\right)$ recorded lowest root length $(4.98 \mathrm{~cm}, 6.56 \mathrm{~cm}, 10.99 \mathrm{~cm}$ and 14.66 $\mathrm{cm}$ respectively). On the other hand, the highest root dry weight at 15 DAT, 30 DAT, 60 DAT and 90 DAT were also found in treatment $\mathrm{T}_{2}(0.13 \mathrm{~g}, 0.19 \mathrm{~g}, 0.25 \mathrm{~g}$ and $0.31 \mathrm{~g}$ respectively) and the minimum values were seen in $\mathrm{T}_{1}(0.04 \mathrm{~g}, 0.11 \mathrm{~g}, 0.19 \mathrm{~g}$ and $0.25 \mathrm{~g}$ respectively). While considering root dry weight, it was observed that the different fertilizer sources did not leave a variable influence on that plant character.

All those treatments equally contributed to the root dry weight. But in general, the phosphate solubilising bacteria has a stimulating effect on root development probably often triggered by phytohormones. The main effect of PSB is stimulation of the density and length of root hairs, the rate of appearance of lateral roots and the root surface area. From this experiment it was also revealed that the treatments in which phosphate solubilising bacteria like Bacillus polymyxa and Pseudomonas fluorescence were applied, showed a beneficial role on root development. 


\section{Effect on growth and yield parameters}

The growth and yield attributes of rice such as plant height, leaf area index, number of tillers hill ${ }^{-1}$, panicle length, effective tillers hill ${ }^{-1}$, number of spikelets panicle ${ }^{-1}$, number of chaffy grains panicle ${ }^{-1}$, number of filled grains panicle $^{-1}$, test weight of grains, grain and straw yield, biological yield and harvest index are presented in Table 3, 4 and 5. Application of different fertilizers has shown significant improvement in all growth and yield parameters than control. $\mathrm{T}_{2}$ treatment i.e. application of inorganic fertilizer at $100 \%$ recommended dose recorded significantly highest plant height $(105.60 \mathrm{~cm})$ among different fertilizer sources. $\mathrm{T}_{2}$ treatment was statistically at par with $\mathrm{T}_{4}$ and $\mathrm{T}_{5}$ treatments (103.93 cm and $102.60 \mathrm{~cm}$ respectively) and the lowest plant height $(93.67 \mathrm{~cm})$ was found in $\mathrm{T}_{1}$. The addition of macronutrients $\mathrm{N}, \mathrm{P}$ and $\mathrm{K}$ through full dose of inorganic fertilizer in soil resulted in increased plant height.

Bio-fertilizer sources supply plant nutrients as well as plant growth regulators and humic acid and they have additive effect on plant growth (Tomati et al., 1988). Although plant height is the genetic character but it is largely influenced by the availability of nitrogen in soil. Nitrogen plays an important role in overall growth of the crop. Any restriction in the supply of this mineral element, particularly at early growth stage, may limit the crop growth. The highest leaf area index was noted in $\mathrm{T}_{2}$ (3.81) which was statistically at par with $\mathrm{T}_{4}$ treatment (3.67) and $\mathrm{T}_{1}$ recorded the lowest LAI (2.89). Leaf area index is directly related with the vegetative growth of the crop which is influenced by the availability of plant nutrient in soil (De Datta, 1981). Azotobacter also influences LAI positively particularly at later growth stage by supplying nitrogen to the plant. Kader et al., (2000) also reported similar growth trend of LAI due to Azotobacter inoculation. Venkataraman
(1982) stated that Azotobacter accelerated the growth of crops by supplying nitrogen and growth stimulating substances. It is observed from this experiment that reduction of NPK fertilizer by $25 \%$ did not reduce LAI significantly and it was at par with maximum doses of NPK fertilizer. This amount of chemical fertilizer was supplemented from bio-fertilizer.

Full recommended dose of inorganic fertilizer in $\mathrm{T}_{2}$ treatment recorded the highest number of tillers hill $^{-1}$ (15.19). As expected, the control treatment i.e. $\mathrm{T}_{1}$ gave the lowest number of tillers hill $^{-1}$ (11.68). $\mathrm{T}_{2}$ treatment was significantly superior to $\mathrm{T}_{1}, \mathrm{~T}_{3}, \mathrm{~T}_{6}$ and $\mathrm{T}_{7}$ treatments but maintained similarity with $\mathrm{T}_{4}$ (15.04) and $T_{5}$ (14.67) treatments. Tillering is largely related with genetic behavior of a variety. It is the outcome of the expansion of auxiliary buds, which is closely associated with the nutritional condition of the mother culm, and a tiller receives carbohydrate and nutrients from the mother culm during its early growth period which gets improved by the application of $\mathrm{N}$ (Tisdale and Nelson, 1975). However, many workers found a close relationship between nutrient management and tiller number. Alam et al., (2009) found that the tiller productions are highly responsive to available phosphorus level in soil. Amin et al., (2006) also reported that irrespective of varietal differences higher the nitrogen, greater was the number of tillers. Increase in tiller production with higher supply of plant nutrients might be probably due to the greater supply of $\mathrm{N}$ with efficient utilization for cell multiplication and enlargement and formation of nucleic acids and other vitally important organic compounds in the cell sap (Chadravanshi and Singh, 1974). Similar trends of results were also observed in case of panicle length. The highest panicle length $(24.50 \mathrm{~cm})$ was found in $\mathrm{T}_{2}$ treatment, statistically at par with $\mathrm{T}_{4}(24.30 \mathrm{~cm})$ and $\mathrm{T}_{5}$ $(24.26 \mathrm{~cm})$ treatments. 
Table.1 Effect of inorganic and bio-fertilizers on root length of rice

\begin{tabular}{|c|c|c|c|c|}
\hline Treatments & & Root length (cm) & & \\
\hline & 15 DAT & 30 DAT & 60 DAT & 90 DAT \\
\hline$\overline{T_{1}}$ & 4.98 & 6.56 & 10.99 & 14.66 \\
\hline$T_{2}$ & 5.56 & 7.63 & 13.98 & 16.73 \\
\hline$T_{3}$ & 5.18 & 7.19 & 12.87 & 15.81 \\
\hline$\overline{T_{4}}$ & 5.23 & 7.28 & 13.03 & 15.92 \\
\hline$T_{5}$ & 5.36 & 7.60 & 13.19 & 16.25 \\
\hline$T_{6}$ & 5.16 & 7.45 & 12.64 & 15.90 \\
\hline$T_{7}$ & 5.13 & 7.33 & 12.52 & 15.49 \\
\hline S.Em. ( \pm$)$ & 0.17 & 0.24 & 0.49 & 0.63 \\
\hline C.D. $(P=0.05)$ & 0.53 & 0.74 & 1.52 & 1.95 \\
\hline
\end{tabular}

Table.2 Effect of inorganic and bio-fertilizers on root dry weight of rice

\begin{tabular}{|l|c|c|c|c|}
\hline Treatments & & Root dry weight $(\mathrm{g})$ & & \\
\hline & 15 DAT & 30 DAT & 60 DAT & 90 DAT \\
\hline $\mathrm{T}_{1}$ & 0.04 & 0.11 & 0.19 & 0.25 \\
\hline $\mathrm{T}_{2}$ & 0.13 & 0.19 & 0.25 & 0.31 \\
\hline $\mathrm{T}_{3}$ & 0.07 & 0.16 & 0.22 & 0.28 \\
\hline $\mathrm{T}_{4}$ & 0.09 & 0.17 & 0.20 & 0.29 \\
\hline $\mathrm{T}_{5}$ & 0.09 & 0.18 & 0.23 & 0.29 \\
\hline $\mathrm{T}_{6}$ & 0.07 & 0.16 & 0.19 & 0.26 \\
\hline $\mathrm{T}_{7}$ & 0.06 & 0.15 & 0.18 & 0.27 \\
\hline S.Em. $( \pm)$ & $\mathbf{0 . 0 3}$ & $\mathbf{0 . 0 4}$ & $\mathbf{0 . 0 6}$ & $\mathbf{0 . 0 9}$ \\
\hline C.D. $(\mathrm{P}=\mathbf{0 . 0 5})$ & $\mathbf{0 . 0 9}$ & $\mathbf{0 . 1 2}$ & $\mathbf{0 . 1 9}$ & $\mathbf{0 . 2 8}$ \\
\hline
\end{tabular}

Table.3 Effect of inorganic and bio-fertilizers on different growth and yield parameters of rice

\begin{tabular}{|l|c|c|c|c|}
\hline Treatments & $\begin{array}{c}\text { Plant height } \\
(\mathbf{c m})\end{array}$ & $\begin{array}{c}\text { Leaf area } \\
\text { index }\end{array}$ & $\begin{array}{c}\text { No. of } \\
\text { tillers hill }^{-1}\end{array}$ & $\begin{array}{c}\text { Panicle } \\
\text { length }(\mathbf{c m})\end{array}$ \\
\hline $\mathrm{T}_{1}$ & 93.67 & 2.89 & 11.68 & 21.80 \\
\hline $\mathrm{T}_{2}$ & 105.60 & 3.81 & 15.19 & 24.50 \\
\hline $\mathrm{T}_{3}$ & 100.03 & 3.59 & 14.51 & 22.96 \\
\hline $\mathrm{T}_{4}$ & 103.93 & 3.67 & 15.04 & 24.30 \\
\hline $\mathrm{T}_{5}$ & 102.60 & 3.21 & 14.67 & 24.26 \\
\hline $\mathrm{T}_{6}$ & 100.13 & 3.28 & 13.89 & 23.33 \\
\hline $\mathrm{T}_{7}$ & 98.76 & 3.02 & 13.10 & 20.96 \\
\hline S.Em. $( \pm)$ & $\mathbf{1 . 6 2}$ & $\mathbf{0 . 0 9}$ & $\mathbf{0 . 1 8}$ & $\mathbf{0 . 2 2}$ \\
\hline C.D. $(\mathbf{P}=\mathbf{0 . 0 5})$ & $\mathbf{5 . 0 0}$ & $\mathbf{0 . 1 9}$ & $\mathbf{0 . 5 6}$ & $\mathbf{0 . 6 8}$ \\
\hline
\end{tabular}


Table.4 Effect of inorganic and bio-fertilizers on yield parameters of rice

\begin{tabular}{|l|c|c|c|c|c|}
\hline Treatments & $\begin{array}{c}\text { Effective } \\
\text { tillers hill } \\
1\end{array}$ & $\begin{array}{c}\text { No. of } \\
\text { spikelets } \\
\text { panicle }^{-1}\end{array}$ & $\begin{array}{c}\text { No. of chaffy } \\
\text { grains panicle }\end{array}$ & $\begin{array}{c}\text { No. of } \\
\text { filled } \\
\text { grains } \\
\text { panicle }^{-1}\end{array}$ & $\begin{array}{c}\text { Test } \\
\text { weight } \\
(\mathrm{g})\end{array}$ \\
\hline $\mathrm{T}_{1}$ & 10.10 & 85.52 & 21.79 & 116.61 & 17.40 \\
\hline $\mathrm{T}_{2}$ & 13.60 & 94.68 & 15.82 & 127.00 & 20.10 \\
\hline $\mathrm{T}_{3}$ & 12.19 & 87.10 & 17.38 & 124.02 & 19.53 \\
\hline $\mathrm{T}_{4}$ & 13.37 & 92.34 & 16.23 & 126.70 & 19.83 \\
\hline $\mathrm{T}_{5}$ & 13.08 & 91.17 & 16.38 & 125.59 & 19.66 \\
\hline $\mathrm{T}_{6}$ & 11.79 & 86.59 & 18.16 & 123.82 & 18.93 \\
\hline $\mathrm{T}_{7}$ & 10.73 & 86.14 & 19.84 & 122.70 & 18.60 \\
\hline S.Em. $( \pm)$ & $\mathbf{0 . 2 0}$ & $\mathbf{2 . 3 5}$ & $\mathbf{1 . 3 7}$ & $\mathbf{0 . 3 2}$ & $\mathbf{0 . 1 7}$ \\
\hline C.D. $(\mathbf{P}=\mathbf{0 . 0 5}$ & $\mathbf{0 . 6 2}$ & $\mathbf{7 . 2 9}$ & $\mathbf{4 . 2 5}$ & $\mathbf{0 . 9 8}$ & $\mathbf{0 . 5 2}$ \\
\hline
\end{tabular}

Table.5 Effect of inorganic and bio-fertilizers on yield of rice

\begin{tabular}{|l|c|c|c|c|}
\hline Treatments & $\begin{array}{c}\text { Grain yield } \\
\left(\mathrm{t} \mathrm{ha}^{-1}\right)\end{array}$ & $\begin{array}{c}\text { Straw yield } \\
\left(\mathrm{t} \mathrm{ha}^{-1}\right)\end{array}$ & $\begin{array}{c}\text { Biological yield } \\
\left(\mathrm{t} \mathrm{ha}^{-1}\right)\end{array}$ & $\begin{array}{c}\text { Harvest Index } \\
(\%)\end{array}$ \\
\hline $\mathrm{T}_{\mathbf{1}}$ & 4.72 & 5.88 & 10.60 & 44.53 \\
\hline $\mathrm{T}_{2}$ & 5.66 & 6.99 & 12.65 & 44.74 \\
\hline $\mathrm{T}_{3}$ & 5.22 & 6.48 & 11.70 & 44.62 \\
\hline $\mathrm{T}_{4}$ & 5.48 & 6.93 & 12.41 & 44.12 \\
\hline $\mathrm{T}_{5}$ & 5.40 & 6.67 & 12.07 & 44.74 \\
\hline $\mathrm{T}_{6}$ & 5.12 & 6.29 & 11.41 & 44.87 \\
\hline $\mathrm{T}_{7}$ & 4.98 & 6.12 & 11.10 & 44.86 \\
\hline $\mathrm{S} . \mathrm{Em} \cdot( \pm)$ & $\mathbf{0 . 1 3}$ & $\mathbf{0 . 1 1}$ & $\mathbf{0 . 1 3}$ & $\mathbf{0 . 6 7}$ \\
\hline $\mathrm{CD}(\mathrm{P}=\mathbf{0 . 0 5})$ & $\mathbf{0 . 3 9}$ & $\mathbf{0 . 3 4}$ & $\mathbf{0 . 2 9}$ & $\mathbf{1 . 4 5}$ \\
\hline
\end{tabular}

In our experiment, significantly higher number of effective tillers hill ${ }^{-1}$ was seen in $T_{2}$ (13.60) and the minimum value was found in control i.e. $\mathrm{T}_{1}$ (10.10). The $\mathrm{T}_{2}$ treatment was significantly different from all the treatments except $\mathrm{T}_{4}(13.37)$ and $\mathrm{T}_{5}$ (13.08) treatments. In the present study, number of effective tillers hill $^{-1}$ increased with the increasing amount of chemical fertilizer and reaches maximum where full recommended dose of chemical fertilizer were applied. Along with inorganic fertilizer, different bio-fertilizers played a significant role in increasing effective tiller number. Rice plants require large amount nitrogen at early and mid tillering stages which promote rapid growth, increased height and tiller number which was documented by De Datta (1981). Phosphate plays an important role to convert tillers to effective tillers. Santai et al., (2011) reported that the number of effective tillers was considerably influenced by the rate nitrogen fertilizer. It was observed that amount of chemical fertilizer at full recommended dose $\left(\mathrm{T}_{2}\right)$ produced maximum spikelets per panicle (94.68) which was statistically at par with $\mathrm{T}_{4}$ (92.34) and $T_{5}$ (91.17) treatments. Inorganic fertilizer along with bio-fertilizer largely governed the number of spikelets per panicle. The bio-fertilizers substituted $25 \%$ NPK without any loss in the number of spikelets per 
panicle. Nitrogen plays an important role to increase the number of spikelets per panicle particularly when it is sufficiently available at panicle initiation stage (De Datta, 1981). The number of chaffy grains per panicle was highest in control treatment (21.79) due to lack of nutrient supply but the lowest value (15.82) was found in $\mathrm{T}_{2}$ where full recommended dose of inorganic fertilizer was applied. Besides in the present study, the observations clearly indicate that the amount of chemical fertilizer also played a significant role in the grain filling. Significant contribution of bio-fertilizers in combination with inorganic fertilizer was realized when it was applied with $25 \%$ less chemical fertilizer than recommended dose. The highest number of filled grains was recorded in $\mathrm{T}_{2}$ (127.00) and it was statistically at par with $\mathrm{T}_{4}$ (126.70) treatment. Significantly lowest number filled grains were recorded in $T_{1}$ (116.61). In case of test weight, $T_{2}$ treatment recorded highest test weight of grains $(20.10 \mathrm{~g})$ which was statistically at par with $\mathrm{T}_{4}(19.83)$ and $\mathrm{T}_{5}(19.66 \mathrm{~g})$ treatments. $\mathrm{T}_{1}$ treatment recorded significantly lowest test weight (17.40 g) than all other treatments.

Grain yield and straw yield were significantly influenced by different fertilizer sources. The grain yield was maximized in $\mathrm{T}_{2}$ treatment (5.66 $\left.\mathrm{t} \mathrm{ha}^{-1}\right)$ which was at par with $\mathrm{T}_{4}\left(5.48 \mathrm{tha}^{-1}\right)$ and $\mathrm{T}_{5}\left(5.40 \mathrm{t} \mathrm{ha}^{-1}\right)$ treatments and significantly superior to rest of the treatments. The lowest grain yield $\left(4.72 \mathrm{t} \mathrm{ha}^{-1}\right)$ was observed in case of control treatment $\left(\mathrm{T}_{1}\right)$. The grain yield is the product of yield attributes like panicle length, number of panicles/hill, filled grains/panicle, test weight etc. In our present investigation, application of full recommended dose of inorganic fertilizer produced highest yield attributes. Reduction of the dose of nitrogen and phosphorus fertilizer up to $25 \%$ of recommended dose was supplemented by biofertilizer. But almost all the yield attributes in this study was drastically reduced when half of the recommended doses of NPK fertilizer were curtailed. On the other hand, application of $100 \%$ recommended dose of inorganic fertilizer resulted the maximum straw yield $\left(6.99 \mathrm{t} \mathrm{ha}^{-1}\right)$ and it was also statistically at par with $\mathrm{T}_{4}(6.93 \mathrm{t}$ $\left.\mathrm{ha}^{-1}\right)$ and $\mathrm{T}_{5}\left(6.67 \mathrm{t} \mathrm{ha}^{-1}\right)$. A field experiment was conducted with rice variety ADT-31 where foliar spray of Azotobacter chroococcum was applied on 15th, 30th and 45th day after transplanting of rice crop. They observed that the foliar spray of Azotobacter culture significantly increased the grain and straw yield of rice crop (Kannaiyan et al., 1980). The lowest $5.88 \mathrm{t} \mathrm{ha}^{-1}$ straw yield was observed in control plot. Satisfying the nutrient requirement of plants through combined application of inorganic fertilizer and bio-fertilizers were also found equally promising in supplying nutrient elements in available form due to rapid release from chemical source as well as slow and steady release from bio-fertilizers in the soil along with essential micronutrients and growth promoting substances which results in higher growth and yield of crops. Similarly, the maximum and minimum biological yield (12.65 $\mathrm{t} \mathrm{ha}^{-1}$ and $10.60 \mathrm{t} \mathrm{ha}^{-1}$ respectively) were recorded in $T_{2}$ and $T_{1}$ treatments respectively. The highest harvest index was noted in $\mathrm{T}_{6}$ (44.87\%) treatment and statistically at par harvest indexes were recorded in $\mathrm{T}_{1}, \mathrm{~T}_{2}, \mathrm{~T}_{3}, \mathrm{~T}_{4}$, $\mathrm{T}_{5}$ and $\mathrm{T}_{7}$ treatments.

In conventional practice, improved cropping system involving high value crops rely on the use of inorganic fertilizers due to its immediate availability of nutrients. Though chemical fertilizers nourish plants, they also jeopardize the environment through nitrate pollution and inflict deleterious effects on the fragile ecosystem with elimination of beneficial soil organisms and deterioration of physical and chemical properties of soil. That's why global attention has been drawn to find out the alternatives and supplements to inorganic fertilizers. The addition of different biofertilizer sources can be a priority to address this problem. Based on the findings of the experiment, it is observed that application of full dose of fertilizer through inorganic sources or their combination results improved root characteristics as well as higher growth and yield parameters of rice as compared to control. It is clearly observed from the present study that 
the reduction of the dose of nitrogen and phosphorus of chemical fertilizer by $25 \%$ did not restrict the growth and yield attributes when it is substituted by the Azotobacter chroococcum and Bacillus polymyxa. Therefore it can be concluded that combined application of bio-fertilizer and inorganic fertilizer i.e. treatment $\mathrm{T}_{4}(75 \%$ recommended dose of $\mathrm{NP}+$ 100\% RDK + Azotobacter chroococcum @ $5 \mathrm{~kg}$ $\left.\mathrm{ha}^{-1}\right)$ and $\mathrm{T}_{5}(75 \%$ recommended dose of NP + $100 \%$ RDK + Bacillus polymyxa @ $5 \mathrm{~kg} \mathrm{ha}^{-1}$ ) can be recommended for achieving higher rice yield in a cost effective manner and also for sustaining soil health and reducing environmental pollution.

\section{References}

Alam, M.M., Mirza, H., and Nahar, K. 2009. Tiller dynamics of three irrigated rice varieties under varying phosphorus levels. American-Eurasian journal of Agronomy. 2(2): 89-94.

Amin, M.R., Hamid, A., Choudhury, S.M., and Asaduzzaman, M. 2006. Nitrogen fertilizer: Effect on tillering, dry matter production and yield of traditional varieties of rice. International Journal of Sustainable Crop Production. 1(1): 17-20.

Chandrasekaran, B., Annadurai, K., Kavimani, R. 2007. A textbook of rice science. Scientific publishers (India), Jodhpur, India, 7.

Chandravanshi, B.R., and Singh, M. 1974. Response of Mexican wheats to fertilizers on grain yield and their attributes. Indian Journal of Agronomy. 19(3):203207.

De Datta, S.K. 1981. Principles and practices of rice production. New York (NY): John Wiley and Sons. Chapter 10, Mineral nutrition and fertilizer management of rice; p. 348-419.

De Dutta, S.K., 1981. Rice growing countries. In: Principles and Practices of rice production. Wiley-Interscience Publication, New York, 4-6.

Kader, M.A., Mamun, A.A., Hossain, S.M.A., and Hasna, M.K. 2000. Effects of Azotobacter application on the growth and yield of transplanted aman rice and nutrient status of post-harvest soil. Pakistan Journal of Biological Sciences; 3(\&): 1144-1147.

Kannaiyan, S., Govindarajan, K., and Lewin, H.D. 1980. Effect of foliar spray of Azotobacter chroococcum on rice crop. Plant and Soil; 56(3):487-490.

Mangla, R. (2004). International year of rice An overview. Indian Farming, 54 (8): 3-6.

Mishra, M.M., Mohanty, M., Gulati, J.M.L., and Nanda, S.S. (2013). Evaluation of various rice (Oryza sativa) based crop sequences for enhanced productivity, profitability and energy efficiency in eastern plateau and hills zone of India. Indian J. Agric. Sci., 83 (12): 1279-1284.

Santai, B.E., Daneshiyam, J., Amir, E., and Azarpour, E. 2011. Study of organic fertilizers displacement in rice sustainable agriculture. Int J Acad Res. 3(2):786.

Tisdale, S.L., and Nelson, W.L. 1975. Soil Fertility and Fertilizers, Third Edition, The Macmillan Publication Co. In. New York.

Tomati, U., Grappelli, A., and Galli, E. 1988. The hormone-like effect of earthworm casts on plant growth. Biology and Fertility of Soils; 5: 288- 294.

Venkataraman, G.S. 1982. Review of soil research in India. Part I. Rekha Printer Pvt. Ltd. New Delhi, India; pp 231.

\section{How to cite this article:}

Malo, M., S. Rath and Dutta, D. 2018. Response of Rice Cultivation to Inorganic and BioFertilizers in New Alluvial Zone of West Bengal. Int.J.Curr.Microbiol.App.Sci. 7(03): 2707-2714. doi: https://doi.org/10.20546/ijcmas.2018.703.313 